\title{
Camera trapping reveals a diverse and unique high-elevation mammal community under threat
}

\author{
Ruthmery Pillco Huarcaya, Christopher Beirne \\ Shirley Jennifer Serrano Rojas and Andrew Whithorth
}

\begin{abstract}
The Cerros del Sira in Peru is known to hold a diverse composition of endemic birds, amphibians and plants as a result of its geographical isolation, yet its mammalian community remains poorly known. There is increasing awareness of the threats to high-elevation species but studying them is often hindered by rugged terrain. We present the first camera-trap study of the mammal community of the Cerros del Sira. We used 45 camera traps placed at regular elevational intervals over $800-1,920 \mathrm{~m}$, detecting 34 mediumsized and large mammal species. Eight are listed as threatened on the IUCN Red List, three are categorized as Data Deficient and one is yet to be assessed. Although other authors have reported that the upper elevations of the Cerros del Sira are free from hunting, we found evidence of hunting activity occurring above $1,400 \mathrm{~m}$, and inside the core protected area. In addition to this direct evidence of hunting, recent information has identified significant amounts of canopy loss in the northern reaches of the core zone. Despite widespread ecological degradation in the surrounding lowlands, the high-elevation areas of the Cerros del Sira still maintain a unique assemblage of lowland and highland tropical rainforest mammals. It has been assumed that the Cerros del Sira and other similar remote locations are safe from disturbance and protected by their isolation but we suggest this is an increasingly dangerous assumption to make, and secure protection strategies need to be developed.
\end{abstract}

Keywords Camera traps, El Sira, habitat loss, hunting, oncilla, Leopardus tigrinus, Peru, spectacled bear, Tremarctos ornatus

Supplementary material for this article is available at https://doi.org/10.1017/So030605318001096

Ruthmery Pillco Huarcaya* (Corresponding author, (D) orcid.org/0000-00030068-3852) and ANDrew Whitworth† Osa Conservation, 1012 14th Street NW, Suite 625, Washington, DC 20005, USA

E-mail ruth.pillcohuarcaya@gmail.com

Christopher BeIRne $\ddagger$ Centre for Ecology and Conservation, University of Exeter, Exeter, UK

Shirley Jennifer Serrano Rojas Universidad Nacional San Antonio Abad del Cusco, Cusco, Peru

*Also at: Universidad Nacional San Antonio Abad del Cusco, Cusco, Peru $\dagger$ Also at: Institute of Biodiversity, Animal Health and Comparative Medicine, College of Medical, Veterinary and Life Sciences, University of Glasgow, Glasgow, UK

\$Also at: Nicholas School of the Environment, Duke University, Durham, North Carolina, USA

Received 8 April 2018. Revision requested 12 June 2018.

Accepted 7 August 2018. First published online 17 April 2019.

\section{Introduction}

The Cerros del Sira is an isolated mountain range in 1 Peru, home to a diverse and unique flora and fauna. The summits rise from the left bank of the Ucayali River, with rugged terrain that extends over five elevational zones $(200-2,230 \mathrm{~m})$. Such isolation predisposes the Cerros del Sira to host a large number of endemic species but also means that these species and their habitats are sensitive to human-driven forest disturbance and climatic change (Forero-Medina et al., 2011). Although climatic changes are not of dramatic consequence for species residing in low-lying well-connected habitat, tropical species in isolated ranges, such as the Cerros del Sira, will have no suitable habitat to shift to, and could be outcompeted by low-elevation species moving to higher altitudes (Tewksbury et al., 2008).

Marginalized and difficult-to-access areas with little attraction for agriculture have historically been passively protected from anthropogenic disturbance. These lands are remote, nutrient poor, and steep, and are ideal for governments to assign for protection (Nelson \& Chomitz, 2011; Harris et al., 2014). However, the passive protection provided by such remoteness is increasingly being questioned (e.g. Poulsen et al., 2017). Evidence indicates that many remote protected regions are undergoing defaunation of medium-sized and large vertebrates ( $\mathrm{Fa}$ et al., 2002; Galetti \& Dirzo, 2013), and fragmented landscapes facilitate access for illegal activities in remote areas (Michalski \& Peres, 2007). In the case of Sira, Novoa et al. (2016) reported the loss of 1,60o ha of forest to agriculture and grazing inside the Sira Communal Reserve during 2013-2016.

Although surveys on birds (Terborgh \& Weske, 1975; Mee et al., 2002; Corvacho et al., 2011; Forero-Medina et al., 2011), amphibians and reptiles (Duellman \& Toft, 1979; Aichinger, 1991), and flowering plants (Wasshausen, 2007; Monteagudo Mendoza \& Huamán Guerrero, 2010) have been carried out in the Cerros del Sira, the mammalian fauna remains poorly documented. Large and mediumsized mammals play a fundamental role in the functioning of Amazonian ecosystems, including control of prey populations (Estes et al., 2011; Ripple et al., 2014, 2016) and seed dispersal (Miller et al., 2001; Fløjgaard et al., 2018), but their large home ranges and slow reproductive rates make them particularly sensitive to habitat fragmentation and hunting (Fisher \& Owens, 2004; Cardillo et al., 2005).

Camera traps are well-suited for surveys in remote locations with poor local infrastructure and harsh terrain 


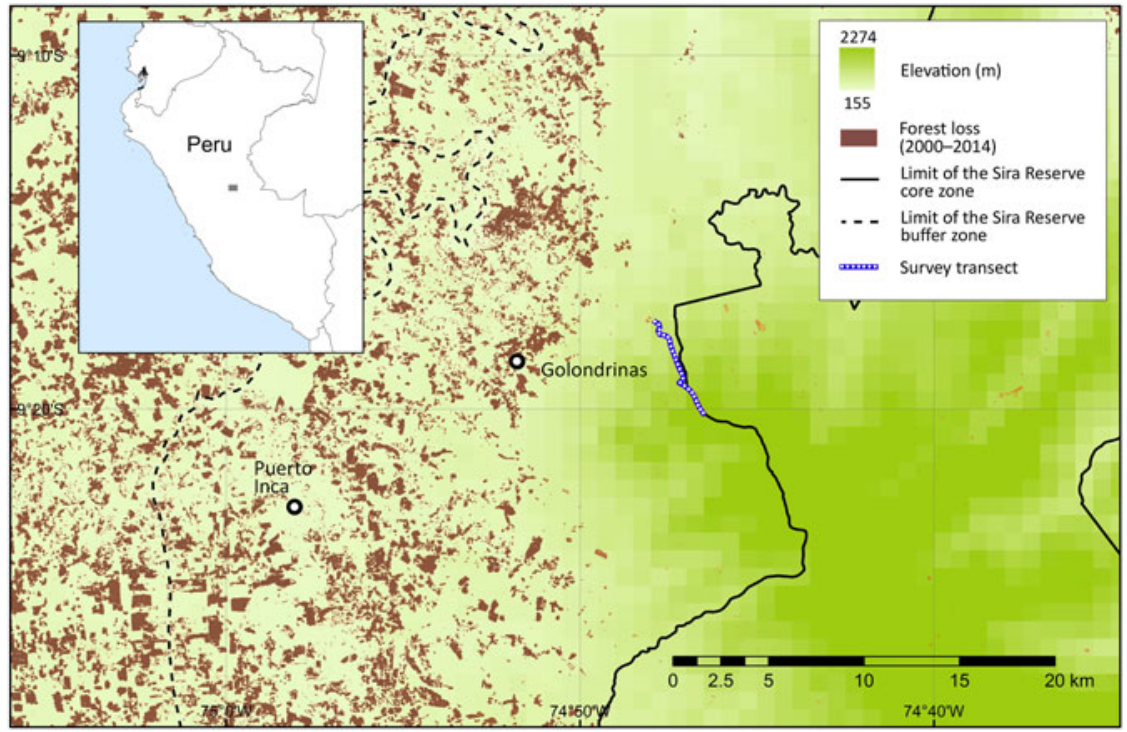

Fig. 1 Location of transect used in a camera-trap survey of medium-sized and large mammals in Sira Communal Reserve, Peru, and deforestation in the region during 2000-2014 (Hansen et al., 2013). (e.g. Jiménez et al., 2010; Beirne et al., 2017), and we present the first camera-trap survey of the mammalian community of the Cerros del Sira. We used 45 terrestrial camera traps over 2 years along a previously unstudied elevational gradient, with the aim of laying a foundation for future research, monitoring and conservation planning efforts in one of the last intact forest landscapes in the central region of the Peruvian Amazon.

\section{Study area}

The Sira Communal Reserve is situated between the Ucayali River to the east and the Pachitea River to the west. It is the largest community reserve in Peru, forming part of the Oxapampa-Asháninka-Yánesha Biosphere Reserve, located in the departments of Pasco, Huánuco and Ucayali, with an area of 616,413 ha and a buffer area of $1,032,340$ ha (INRENA, 2001). The core protected area encompasses the Cerros del Sira Mountains, and the surrounding buffer area comprises a local human population of ethnic groups of Ashaninka, Asheninka, Shipibo-Conibo and Yanesha, and rural communities of Andean migrants (Benavides et al., 2006). Our study transect is to the east of Puerto Inca, in the province of Huánuco (Fig. 1), along a previously unstudied ridgeline on the north-western border of the Sira Communal Reserve. The transect covers both lower and upper montane forests, and elfin forest towards the highest elevations. Mean annual precipitation is c. 3,000 $\mathrm{mm}$ in the montane forest and up to $6,000 \mathrm{~mm}$ on the peaks $(2,220 \mathrm{~m})$. The remoteness of the area has attracted illegal extractive industries, including coca cultivation (for cocaine production), gold mining, poaching and logging. The construction of roads since 2004 has attracted the private sector, with timber and agricultural corporations replacing many of the local cattle farmers. Mining and oil concessions now cover almost the entire area (Finer et al., 2016; Novoa et al., 2016).

\section{Methods}

Camera traps (Trophy Cam, Bushnell, Overland Park, USA) were deployed in mid to late March and removed at the beginning of September (dry season) in 2015 and 2016. Cameras were placed $40 \mathrm{~cm}$ above the ground, and all low vegetation within $3 \mathrm{~m}$ was cleared to standardize detection probabilities. Cameras were programmed to record a $14 \mathrm{~s}$ video, with intervals of $30 \mathrm{~s}$ between successive triggers (Meek et al., 2014; Beirne et al., 2017). Of the 21 cameras deployed in 2015, 19 were set to monitor medium-sized and large vertebrates (including the Critically Endangered Sira curassow Pauxi koepckeae; Beirne et al., 2017) and two were placed at the entry point to the ridgeline ( $865 \mathrm{~m}$ elevation) and at our principal campsite (900 $\mathrm{m}$ ), to monitor hunting activity. Thirteen cameras were placed at elevational intervals of $50 \mathrm{~m}$ between 800 and $1,400 \mathrm{~m}$, four were placed at intervals of $100 \mathrm{~m}$ between 1,500 and $1,800 \mathrm{~m}$ and two were placed at water sources (a clay lick at 1,056 m and a stream at 1,215 m). In 2016, 22 camera traps were placed at elevational intervals of $50 \mathrm{~m}$ between 950 and $1,920 \mathrm{~m}$ to monitor the vertebrate community, and two were placed at the same water source locations used in 2015. As people were also detected by the wildlife cameras along the ridgeline in 2015 , camera traps were not set specifically to target hunting activity in 2016. The camera-trap rate was calculated for every given species as the number of videos/10o camera-trap days. Non-independent events, defined as videos of the same species at the same location within 30 minutes of a previous detection, were excluded from the calculation. 


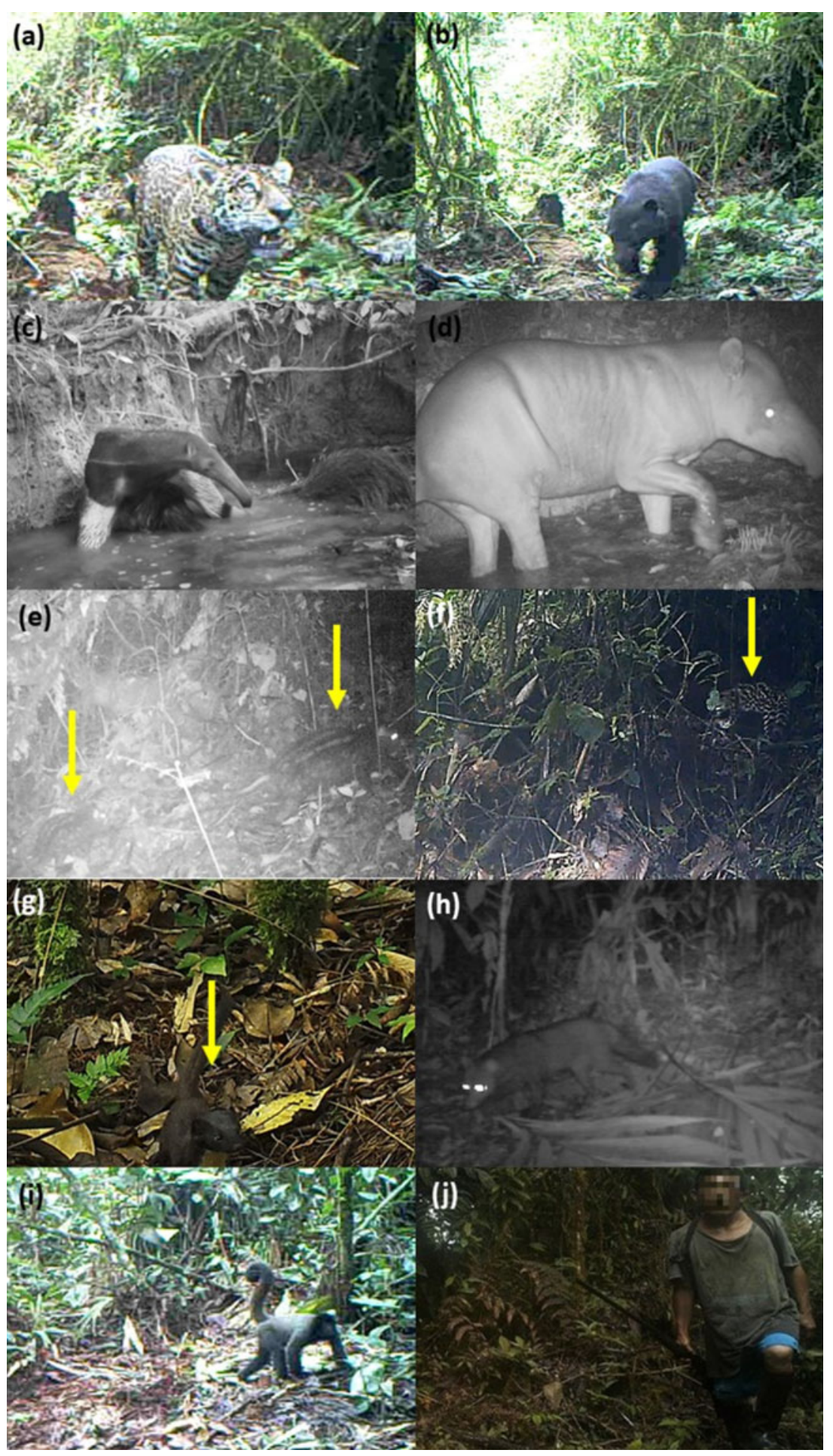

Plate 1 Threatened and rare mammals of the Sira Communal Reserve, Peru (Fig. 1), and direct evidence of hunting activity at high elevations within the Reserve, recorded on camera traps. (a) Panthera onca and (b) Tremarctos ornatus (both captured at the same camera trap, at $1,920 \mathrm{~m}$ ),

(c) Myrmecophaga tridactyla, (d) Tapirus terrestris, (e) Dinomys branickii,

(f) Leopardus tigrinus, (g) Mustela frenata, (h) Atelocynus microtis, (i) Lagothrix cana, and $(\mathrm{j})$ a hunter carrying a shotgun at $1,400 \mathrm{~m}$ within the core area of the Reserve.
Cameras were interfered with by both people and wildlife: jaguars Panthera onca moved three cameras (destroying one completely), spectacled bears Tremarctos ornatus moved four cameras, and people moved two cameras into less effective positions for surveying (i.e. facing dense bushes or the ground). The survey team recorded all incidental audio and visual signs of mediumsized and large mammals while the team was present on the study ridge (6-24 March 2015 and 27 March1 April 2016).

\section{Results}

Overall, we detected 34 medium-sized and large mammal species, belonging to eight orders and 18 families (Plate 1; 
Supplementary Table 1). Thirty mammal species were detected by camera traps, with 1,485 independent records over 6,490 camera-trap nights. Six species of mammals were detected via incidental records, four of which (all arboreal) were not detected by camera traps: the night monkey Aotus nigriceps, the tufted capuchin Sapajus macrocephalus, the burnished saki monkey Pithecia inusta and the kinkajou Potos flavus.

The species accumulation curve from camera data for both 2015 and 2016 shows a clear plateau, indicating that the sampling effort was sufficient to characterize the community of medium-sized and large mammals (Fig. 2). During the first 2,000 camera-trap days most of the mammal community was recorded $\left(S_{\text {obs }}=25\right)$, with only five more species added to the accumulation curve from an additional effort of $>$ 4,000 camera-trap days. The distribution of species across the elevational bands indicates that diversity was highest at 1,000$1,250 \mathrm{~m}$, with the highest observed species richness $\left(S_{\text {obs }}=19\right)$ at $1,250 \mathrm{~m}$. Only five species were detected at $>1,400 \mathrm{~m}$ : the oncilla Leopardus tigrinus, the spectacled bear, the long-tailed weasel Mustela frenata, the Andean white-eared opossum Didelphis pernigra and the pacarana Dinomys branickii. The pacarana was captured only once during the study (at 1,750 m) and the longtailed weasel only on two occasions, at 1,450 and $1,500 \mathrm{~m}$ (Fig. 3; Supplementary Tables $1 \& 2$ ).

Of the 34 species detected, one is categorized as Endangered on the IUCN Red List (the Peruvian woolly monkey Lagothrix cana), four as Vulnerable (the lowland tapir Tapirus terrestris, the spectacled bear, the oncilla and the giant anteater Myrmecophaga tridactyla), and three as Near Threatened (the short-eared dog Atelocynus microtis, the margay Leopardus wiedii and the jaguar). Three of the species detected are categorized as Data Deficient (the South American red brocket deer Mazama americana, the agouti Dasyprocta variegata and the Amazon dwarf squirrel Microsciurus flaviventer), and one is yet to be assessed (the burnished saki monkey). Nineteen of the species detected are listed in the CITES Appendices (CITES, 2017; Supplementary Table 1).

The two cameras placed specifically to monitor human presence within the study site in 2015 detected direct hunting activity (i.e. people with guns or carrying dead wildlife) on seven occasions, and shotgun shells were found frequently on the forest floor. According to our guides, some of the hunters observed in the videos were cocaleros (people hired to harvest coca) and some were working on inventorying trees for a timber concession. One of the videos shows a hunter carrying a dead razorbilled curassow Mitu tuberosum. While camping at 1,350 m we heard two gunshots. Shortly afterwards, camera-trap footage confirmed the presence of hunters carrying two dead woolly monkeys.

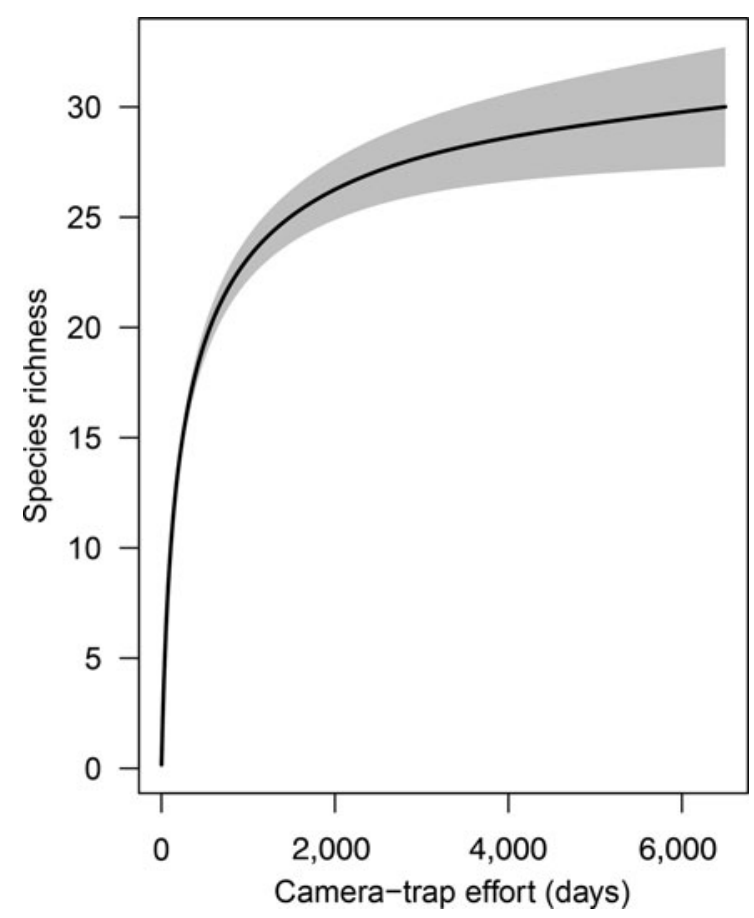

FIg. 2 Species richness accumulation curve with cumulative number of camera-trap nights, for medium-sized and large mammals in Sira Communal Reserve (Fig. 1). The grey shaded area indicates the $95 \%$ confidence interval.

\section{Discussion}

The community of medium-sized and large mammals of the Cerros del Sira is exceptionally diverse, with a unique assemblage of species comprising typical lowland Amazonian species as well as high-elevation species. Illegal hunting activity was detected at $1,400 \mathrm{~m}$ elevation and within the protected area of the Sira Communal Reserve, despite the suggestion that the montane terrain of the Reserve probably receives little attention from hunters (Mee \& Ohlson, 2001).

The species richness of medium-sized and large mammals reported here is higher than that reported from other highland rainforest areas of Peru (Puno $=29$, Apurimac River $=31$, northern Peru $=13$, and Kosñipata $=14 ;$ Pacheco et al., 2007, 2011; Jiménez et al., 2010; Medina et al., 2012). Furthermore, we detected seven species additional to the 40 recorded at nearby lowland Panguana Biological Station (Hutterer et al., 1995). Four of these species have a high-elevation distribution (spectacled bear, oncilla, longtailed weasel and Andean white-eared opossum); the other three are the pacarana, the short-eared dog and the agouti.

Of particular significance was the first detection (to our knowledge) of the two largest land predators in South America at the same camera location, the spectacled bear and the jaguar, on the highest camera, at 1,920 m. Bears were captured at elevations as low as $1,050 \mathrm{~m}$, and both species were subsequently recorded at a camera station at $1,418 \mathrm{~m}$ in Soqtapata Reserve $\left(13.350862^{\circ} \mathrm{S}, 70.84539^{\circ} \mathrm{W}\right)$; 


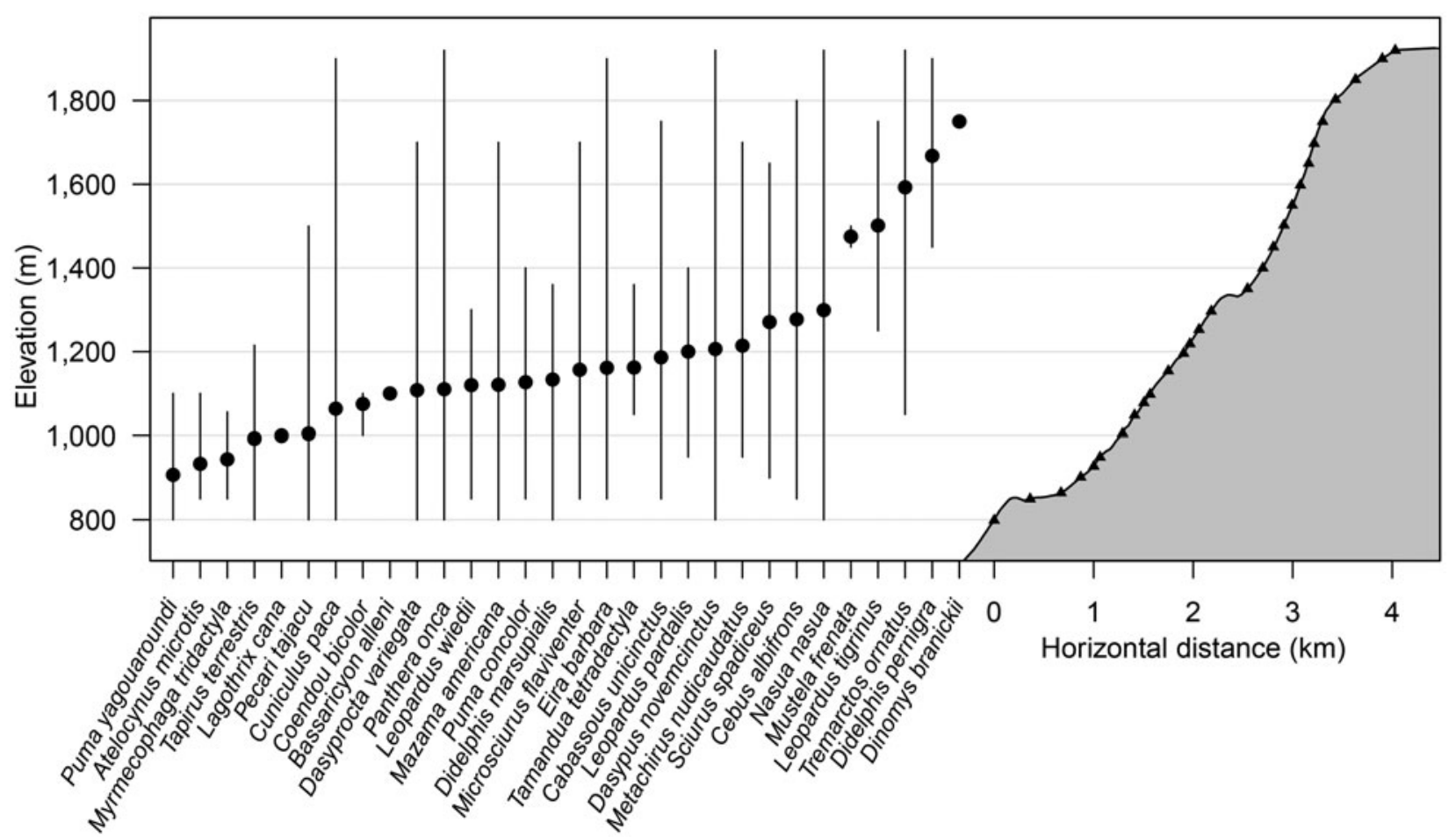

FIG. 3 Elevational distribution of mammal species recorded by camera traps along the survey transect in Sira Communal Reserve (Fig. 1). Cameras placed on trails and at specific habitat features are represented by triangles, mean elevation of detections is represented by filled circles, and maximum and minimum elevation records are represented by vertical lines.

Rafael Pilares, pers. comm.). It has been suggested that the elevation range of these two species in Peru and Bolivia does not overlap anywhere within a single mountain slope, and overlaps only slightly at c. $900 \mathrm{~m}$ throughout the Cordillera Oriental (Servheen et al., 1999). The closest known previous records of the bear to our study area are from the Pachitea Basin, determined by interviews conducted with the inhabitants of the Sira Communal Reserve, and from products derived from bears avaialable for sale in the local markets of Puerto Inca, El Sira and Llullapichis (Figueroa, 2016; Hurtado et al., 2016). Compared to the range of the spectacled bear documented on the IUCN distribution map for the species (Velez-Liendo \& García-Rangel, 2017), our photographic records together with those of Figueroa (2016) and Hurtado et al. (2016) indicate an eastwards extension of c. $100 \mathrm{~km}$. If the bear is distributed throughout the high elevations of the Sira range this could represent an increase in its known habitat of up to 540,000 ha, enough habitat for c. 325 adult individuals, based on previous density estimates from other locations (Kattan et al., 2004; Ríos-Uzeda et al., 2007). As various individual spectacled bears were recorded on several occasions and in different locations, these are unlikely to be records of vagrant individuals.

Another threatened species of note is the oncilla, one of the smallest cats and least known Neotropical mammals (Tortato \& Oliveira, 2005; Hurtado et al., 2016). A search of the literature and museum databases (Hurtado et al., 2016) yielded only 10 records from the past 100 years, of which only three were since 2001, all within the montane forest of the Peruvian Yungas region (Hurtado et al., 2016). Based on the current IUCN distribution map for this species, our records are c. $60 \mathrm{~km}$ west of the known range (Payan \& Oliveira, 2016).

Other large-bodied species of note detected that require large intact habitats include the lowland tapir and the giant anteater, suggesting a high degree of ecological integrity within the core Sira Reserve. The presence of many small, rare and cryptic species, including the margay, the shorteared dog and the pacarana, further underlines the importance of the Reserve in sustaining species of conservation significance (Bickford et al., 2007). The Peruvian woolly monkey is a key species for seed dispersal, supporting carbon stores and maintaining ecosystem viability (Bello et al., 2015; Estrada et al., 2017); it is also a favoured target for hunters, as we discovered, and is susceptible to local extirpation (Peres, 2000).

In addition to the direct evidence of hunting in the Reserve recorded by the camera traps, informal interviews with members of local communities living within the buffer zone confirmed the disappearance of key bushmeat species in nearby lowland areas (in particular the Peruvian woolly monkey, the black-faced spider monkey Ateles chamek and the white-lipped peccary Tayassu pecari). This loss 
of game vertebrates is driving hunting pressure into the upper reaches of the forest within the core reserve area. Subsistence hunting is conducted when the hunter has no viable alternatives, especially where other food options are not readily available (Ripple et al., 2016). During our stay in the communities close to our study site we observed that they reared many animals for personal consumption (chicken, cows, ducks and pigs), and informal conversations confirmed that hunting is practised predominantly as a cultural legacy (enjoying bushmeat, collecting trophies and a social activity with family and friends), not for survival.

In 2016 we witnessed illegal logging inside the core area, at 1,250 m. Previously most anthropogenic impact had occurred outside the core area; however, our direct evidence, along with satellite imagery showing canopy loss in the northern reaches of the core zone (Novoa et al., 2016), indicates this is a real threat to the protected core region. The National Service of Natural Protected Areas (SERNANP) is limited in its capacity to patrol large remote forested landscapes. In such cases, remote sensing technologies such as camera traps and acoustic monitoring devices have been proven to be effective as complementary tools for monitoring illegal activities in protected areas (Hossain et al., 2016).

The remoteness and rugged terrain of the Cerros del Sira has so far protected it from extensive human pressure within the core area of the Reserve. However, evidence of defaunation of other remote areas (Fa et al., 2002; Galetti \& Dirzo, 2013) suggests that we cannot rely on isolation alone to protect this important conservation area. Fragmentation and isolation could be detrimental to the Cerros del Sira; surrounding areas must retain sufficient integrity and connectivity between key protected areas of the OxapampaAsháninka-Yánesha Biosphere Reserve to facilitate species migration and gene flow for viable populations.

Although the surrounding lowlands have been subject to widespread ecological degradation, the high-elevation areas still maintain a unique assemblage of lowland and highland tropical rainforest mammals, many of which are threatened or poorly known. The presence of these species indicates the Reserve has a high degree of ecological integrity and remains one of the few intact wilderness regions (Watson et al., 2018). Although the species in these highlands have thus far been protected from habitat loss, the increasing human population and demand for economic development are exerting increasing pressure on their habitats (Soh et al., 2006). If such pressures are combined with climate change induced range shifts (Forero-Medina et al., 2011), species losses may be catastrophic. There is a need for increased protection of the roadless, intact core area of the Reserve and to ensure the maintenance of connectivity to other key protected areas (Kearney et al., 2018). The development of plans in collaboration with local people and national park authorities to help create viable sustainable livelihoods that limit impacts on biodiversity could foster this, in addition to providing park rangers with the necessary facilities and resources to implement protection of the Reserve.

Acknowledgements We thank all supporters of Exploration Sira: the Royal Geographical Society, with the Institute of British Geographers; the Neville Shulman Challenge Award; Idea Wild; crowdfunder campaign supporters (http://www.crowdfunder.co.uk/exploration-sira); the authorities of Sira Communal Reserve (SERNANP; permits $\left.\mathrm{N}^{\circ} 004-2015-S E R N A N P-R C S \quad \& \quad \mathrm{~N}^{\circ} 003-2016-S E R N A N P-R C S\right)$; Handykam; WildlifeKate; Bushnell Nature; the Scientific Exploration Society for the 2016 Cadogan Tate Explorer Award to AW; B.D. Patterson (Field Museum of Natural History, Chicago) for assistance in identification of Mustela frenata; and the Golondrinas community for providing us with expert local guides.

Author contributions Study design and fieldwork: RPH, AW, CB, JSR; data analysis and writing: RPH, AW, CB.

\section{Conflicts of interest None.}

Ethical standards This research abided by the Oryx Code of conduct; the camera traps did not use flash, and the image of the hunter pictured in Plate 1 was anonymized.

\section{References}

Aichinger, M. (1991) A new species of poison-dart frog (Anura: Dendrobatidae) from the Serranía de Sira, Peru. Herpetologica, $47,1-5$.

Beirne, C., Pillco-Huarcaya, R., Serrano-Rojas, S.J. \& Whitworth, A. (2017) Terrestrial camera traps: essential tool for the detection and future monitoring of the Critically Endangered Sira curassow Pauxi koepckeae. Endangered Species Research, $32,145-152$.

Bello, C., Galetti, M., Pizo, M.A., Magnago, L.F.S., Rocha, M.F., Lima, R.A.F. et al. (2015) Defaunation affects carbon storage in tropical forests. Science Advances, 1, e1501105.

Benavides, M., Barclay, F. \& Smith, R.C. (2006) Atlas de Comunidades Nativas de la Selva Central. Instituto del Bien Común, Lima, Peru.

Bickford, D., Lohman, D.J., Sodhi, N.S., NG, P.K.L., Meier, R., Winker, K. et al. (2007) Cryptic species as a window on diversity and conservation. Trends in Ecology and Evolution, 22, 148-155.

Cardillo, M., Mace, G.M., Jones, K.E., Bielby, J., BinindaEMonds, O.R.P., SEChrest, W. et al. (2005) Multiple causes of high extinction risk in large mammal species. Science, 309, 1239-1241.

CITES (2017) Checklist of CITES species. Http://checklist.cites.org/\% 23/en [accessed 4 February 2018].

Corvacho, M.G., MacLeod, R., Brooks, D.M. \& Hennessey, B. (2011) Distinctive morphology, ecology, and first vocal descriptions of Sira curassow (Pauxi [unicornis] koepckeae): evidence for species rank. Ornitologia Neotropical, 22, 267-279.

Duellman, W.E. \& Toft, C.A. (1979) Anurans from Serranía de Sira, Amazonian Perú: taxonomy and biogeography. Herpetologica, $35,60-70$.

Estes, J.A., Terborgh, J., Brashares, J.S., Power, M.E., Berger, J., Bond, W.J. et al. (2011) Trophic downgrading of planet Earth. Science, 333, 301-306.

Estrada, A., Garber, P.A., Rylands, A.B., Roos, C., Fernandez-Duque, E., Di Fiore, A. et al. (2017) Impending extinction crisis of the world's primates: why primates matter. Science Advances, 3, e1600946. 
FA, J.E., Peres, C.A. \& Meeuwig, J. (2002) Bushmeat exploitation in tropical forests: an intercontinental comparison. Conservation Biology, 16, 232-237.

Figueroa, J. (2016) Ecología y conservación del oso andino (Tremarctos ornatus) en las Áreas Naturales Protegidas del Perú. $\mathrm{PhD}$ thesis. Universidad de Alicante, Alicante, Spain.

Finer, M., Novoa, S., Cruz, C. \& Peña, N. (2016) Hotspot de Deforestación en la Selva Central (region Huánuco). MAAP: 37. Monitoring of the Andean Amazon Project. Amazon Conservation, Washington, DC, USA and Conservación Amazónica, Lima, Peru.

Fisher, D.O. \& Owens, I.P.F. (2004) The comparative method in conservation biology. Trends in Ecology and Evolution, 19, 391-398.

Fløjgaard, C., Bruun, H.H., Hansen, M.D.D., HeilmannClausen, J., Svenning, J.-C. \& EjRnaes, R. (2018) Are ungulates in forests concerns or key species for conservation and biodiversity? Reply to Boulanger et al. (DOI: 10.1111/gcb.13899). Global Change Biology, 24, 869-871.

Forero-Medina, G., Terborgh, J., Socolar, S.J. \& Pimm, S.L. (2011) Elevational ranges of birds on a tropical montane gradient lag behind warming temperatures. PLOS ONE, 6, e28535.

Galetti, M. \& Dirzo, R. (2013) Ecological and evolutionary consequences of living in a defaunated world. Biological Conservation, 163, 1-6.

Hansen, M.C., Potapov, P.V., Moore, R., Hancher, M., Turubanova, S.A., Tyukavina, A. et al. (2013) High-resolution global maps of 21st-century forest cover change. Science, $342,850-853$.

Harris, J.B.C., Dwi Putra, D., Gregory, S.D., Brook, B.W., Prawiradilaga, D.M., Sodhi, N.S. et al. (2014) Rapid deforestation threatens mid-elevational endemic birds but climate change is most important at higher elevations. Diversity and Distributions, 20, 773-785.

Hossain, A.N.M., Barlow, A., Barlow, C.G., Lynam, A.J., Chakma, S. \& SAVINI, T. (2016) Assessing the efficacy of camera trapping as a tool for increasing detection rates of wildlife crime in tropical protected areas. Biological Conservation, 201, 314-319.

Hurtado, C.M., Pacheco, V., Fajardo, Ú. \& Uturunco, A. (2016) An updated analysis of the distribution of CITES-listed Peruvian carnivores for conservation priorities. Mastozoología Neotropical, 23, 415-429.

Hutterer, R., Verhaagh, M., Diller, J. \& Podloucky, R. (1995) An inventory of mammals observed at Panguana Biological Station, Amazonian Peru. Ecotropica, 1, 3-20.

INRENA (2001) DS No o37-2001-AG. Crean la Reserva Comunal El Sira. Http://legislacionanp.org.pe/reserva-comunal-el-sira/ [accessed 3 January 2018].

IUCN (2017) The IUCN Red List of Threatened Species v. 2017.3. Http://www.iucnredlist.org/ [accessed 10 March 2018].

Jiménez, C.F., Quintana, H., Pacheco, V., Melton, D., Torrealva, J. \& Tello, G. (2010) Camera trap survey of medium and large mammals in a montane rainforest of northern Peru. Revista Peruana de Biología, 17, 191-196.

Kattan, G., Hernández, O.L., Goldstein, I., Rojas, V., Murillo, O., Gomez, C. et al. (2004) Range fragmentation in the spectacled bear Tremarctos ornatus in the northern Andes. Oryx, 38, 155-163.

Kearney, S.G., Adams, V.M., Fuller, R.A., Possingham, H.P. \& WAtson, J.E.M. (2018) Estimating the benefit of well-managed protected areas for threatened species conservation. Oryx, published online 31 May 2018.

Medina, C.E., Zeballos, H. \& López, E. (2012) Diversidad de mamiferos en los bosques montanos del valle de Kcosñipata Cusco, Peru. Mastozoología Neotropical, 19, 85-104.
Mee, A. \& Ohlson, J. (2001) A Preliminary Assessment of the Biological Importance of the Cerros del Sira, Department of Huánuco, Peru. ProAves Perú, Piura, Peru, Instituto Nacional de Recursos Naturales, Lima, Peru, and Asociación Interétnica de Desarrollo de la Selva Peruana, Lima, Peru.

Mee, A., Ohlson, J., Stewart, I., Wilson, M., Örn, P. \& Diaz Ferreyra, J. (2002) The Cerros del Sira revisited: birds of submontane and montane forest. Cotinga, 18, 46-57.

Meek, P.D., Ballard, G., Claridge, A., Kays, R., Moseby, K., O'Brien, T. et al. (2014) Recommended guiding principles for reporting on camera trapping research. Biodiversity and Conservation, 23, 2321-2343.

Michalski, F. \& Peres, C.A. (2007) Disturbance-mediated mammal persistence and abundance-area relationships in Amazonian forest fragments. Conservation Biology, 21, 1626-1640.

Miller, B., Dugelby, B., Foreman, D., Martinez del Río, C., Noss, R., Phillips, M. et al. (2001) The importance of large carnivores to healthy ecosystems. Endangered Species UPDATE, $18,202-210$.

Monteagudo Mendoza, A.L. \& Huamán Guerrero, M. (2010) Catálogo de los árboles y afines de la Selva Central del Perú. Arnaldoa, 17, 203-242.

Nelson, A. \& Chомitz, K.M. (2011) Effectiveness of strict vs. multiple use protected areas in reducing tropical forest fires: a global analysis using matching methods. PLOS ONE, 6, e22722.

Novoa, S., Finer, M. \& Snelgrove, C. (2016) Threats to Peru's El Sira Communal Reserve. MAAP: 45. Monitoring of the Andean Amazon Project. Amazon Conservation, Washington, DC, USA and Conservación Amazónica, Lima, Peru.

Pacheco, V., Salas, E., Cairampoma, L., Noblecilla, M., Quintana, H., Ortiz, F. et al. (2007) Contribución al conocimiento de la diversidad y conservación de los mamíferos en la cuenca del río Apurímac, Perú. Revista Peruana de Biología, $14,169-180$.

Pacheco, V., Márquez, G., Salas, E. \& Centty, O. (2011) Diversidad de mamíferos en la cuenca media del río Tambopata, Puno, Perú. Revista Peruana de Biología, 18, 231-244.

Payan, E. \& Oliveira, T. (2016) Leopardus tigrinus. In The IUCN Red List of Threatened Species 2016: e.T54012637A50653881. Http://dx.doi. org/10.2305/IUCN.UK.2016-2.RLTS.T54012637A50653881.en [accessed 11 September 2018].

Peres, C.A. (200o) Evaluating the impact and sustainability of subsistence hunting at multiple Amazonian forest sites. In Hunting for Sustainability in Tropical Forests (eds E.L. Bennett \& J.C. Robinson), pp. 31-57. Columbia University Press, New York, USA.

Poulsen, J.R., Koerner, S.E., Moore, S., Medjibe, V.P., Blake, S., Clark, C.J. et al. (2017) Poaching empties critical Central African wilderness of forest elephants. Current Biology, 27, PR134-R135.

Ríos-Uzeda, B., Gómez, H. \& Wallace, R.B. (2007) A preliminary density estimate for Andean bear using camera-trapping methods. Ursus, 18, 124-128.

Ripple, W.J., Estes, J.A., Beschta, R.L., Wilmers, C.C., Ritchie, E. G., Hebilewhite, M. et al. (2014) Status and ecological effects of the world's largest carnivores. Science, 343, 1241484.

Ripple, W.J., Abernethy, K., Betts, M.G., Chapron, G., Dirzo, R., Galetti, M. et al. (2016) Bushmeat hunting and extinction risk to the world's mammals. Royal Society Open Science, 3, 160498.

Servheen, C., Herrero, S. \& Peyton, B. (1999) Spectacled bear conservation action plan. In Status, Survey and Conservation Action Plan: Bears (eds IUCN/SSC Bear and Polar Bear Specialist Group), pp. 157-198. IUCN, Gland, Switzerland and Cambridge, UK. 
SoH, M.C.K., Sodhi, N.S. \& Lim, S.L.H. (2006) High sensitivity of montane bird communities to habitat disturbance in Peninsular Malaysia. Biological Conservation, 129, 149-166.

Terborgh, J. \& Weske, J.S. (1975) The role of competition in the distribution of Andean birds. Ecology, 56, 562-576.

Tewnsbury, J.J., Huey, R.B. \& Deutsch, C.A. (2008) Putting the heat on tropical animals. Science, 320, 1296-1297.

Tortato, M.A. \& Oliveira, T.G. (2005) Ecology of the oncilla (Leopardus tigrinus) at Serra do Tabuleiro State Park, southern Brazil. CAT News, 42, 28-30.
Velez-Liendo, X. \& García-Rangel, S. (2017) Tremarctos ornatus. In The IUCN Red List of Threatened Species 2017: e.T22066A123792952. Http://dx.doi.org/10.2305/IUCN.UK.2017-3. RLTS.T22066A45034047.en [accessed 10 January 2019].

Wasshausen, D.C. (2007) A checklist of the Acanthaceae collected in the "Sira mountains" of Peru. Annalen des Naturhistorischen Museums in Wien, 108B, 167-190.

Watson, J.E.M., Evans, T., Venter, O., Williams, B., Tulloch, A., Stewart, C. et al. (2018) The exceptional value of intact forest ecosystems. Nature Ecology \& Evolution, 2, 599-610. 